\title{
Journal of Pharmacy
}

\section{Antimicrobial Study of Chloroform Fraction from the Leaves of Entada spiralis Ridl.}

\author{
Fitri Rachmadita ${ }^{1}$, Erryana Martati ${ }^{1}$, Sharifah Nurul Akilah Syed Mohamad ${ }^{2}$ and Siti Zaiton Mat \\ So' ${ }^{2}{ }^{2,{ }^{*}}$
}

\section{ABSTRACT}

Introduction: Entada Spiralis Ridl., or locally identified as Sintok, contains flavonoid, saponin, tannin, and glycoside, compounds that have antifungal and antibacterial activities. This research aims to identify bioactive compounds and determine the antimicrobial activity from crude and fraction of $E$. spiralis extract.

Methods: The crude extract was prepared by macerating the leaves with chloroform, and then proceeded to fraction it by vacuum liquid chromatography with Dichloromethane (DCM)/Hexane (Hex) (1/9) and Dichloromethane (DCM)/Methanol (MeOH) (9/1) solvent system. Disk Diffusion Test and Microdilution Assay evaluated the extracts' antimicrobial activity against $S$. aureus, $E$. coli and $C$. albicans. The determination of bioactive compounds was done by Thin Layer Chromatography (TLC). Determination of Total Phenolic (TPC) and Flavonoid Content (TFC) were performed by Folin-Ciocalteu and $\mathrm{AlCl}_{3}$ Colourimetric Assay

Results: The greatest inhibition zone against $C$. albicans was obtained from fraction Chloroform $\left(\mathrm{CHCl}_{3}\right)$ extract with an inhibition zone of $10.33 \mathrm{~mm}$. DCM/MeOH (9/1) effectively killed $\mathrm{S}$. aureus and E.coli with an inhibition zone of 11.67 and $12 \mathrm{~mm}$, respectively. The minimum inhibitory concentration (MIC) of $\mathrm{CHCl}_{3}$ crude extract were $1.563 \mathrm{mg} / \mathrm{mL}$ for both $E$. coli and S. aureus, and $0.781 \mathrm{mg} / \mathrm{mL}$ for $C$. albicans. The TLC revealed the presence of tannins, saponin, glycosides, phenol, flavonoid, triterpenoid, and aromatic compound in $\mathrm{CHCl}_{3}$ crude extract. TPC of DCM/MeOH (9/1), $\mathrm{CHCl}_{3}$, and DCM/Hex (1/9) were $50.56 \pm 0.188,51.913 \pm 0.089,24.16 \pm$ $0.175 \mathrm{mg}$ GAE/g extract.

Conclusion: In conclusion, $E$. spiralis leaves could be a source of active antifungal and antimicrobial agents used for food preservation by using a semipolar solvent for extraction.

\section{*Corresponding author:}

Email address: dszaiton@iium.edu.my Tel: +60139843575

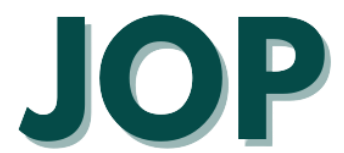

\section{ARTICLE HISTORY:}

Received: 5 August 2020

Accepted: 5 November 2020

Published: 8 January 2021

\section{KEYWORDS:}

Antimicrobial, chloroform, Entada spiralis, fraction.

\section{HOW TO CITE THIS \\ ARTICLE:}

Rachmadita, F., Martati, E., Mohamad, S. N. A. S. \& So'ad, S. Z. M. (2021). Antimicrobial Study of Chloroform Fraction from the Leaves of Entada spiralis Ridl. Journal of Pharmacy, 1(1), 45-53.

\author{
Authors' Affiliation: \\ ${ }^{1}$ Department of Food Science and Technology, Faculty of Agricultural Technology, \\ Brawijaya University, Malang, East Java, Indonesia. \\ 2 Department of Pharmaceutical Chemistry, Kulliyyah of Pharmacy, International \\ Islamic University Malaysia (IIUM), Jalan Sultan Ahmad Shah, 25200 Kuantan, \\ Pahang, Malaysia.
}




\section{Introduction}

Nowadays, researchers pay more attention to natural antimicrobials, such as extracts from plants, to preserve food and modern medicine. This issue is related to the increase of public concern over chemical and synthetic preservatives. About three-quarters of the world population was estimated to depend mainly on plants and plant extracts for their health care because synthetic products could cause postural hypertension, heart failure, and impotence (Zhang et al., 2013). One of the potential plants is E. spiralis. Ridley, (synonym, Entada scheffleri), locally known as Sintok, Sea Bean, or Beluru, from Leguminosae. Traditionally, it is used for hair treatment and as a cleaner for some skin disease. This plant is a tropical liana or woody climber that could go up to $25 \mathrm{~m}$ long (National Park, 2019), and it is commonly found in Australia and Southeast Asia. A previous study showed that $E$. spiralis stem bark contains flavonoid, saponin, tannin, and glycoside (Harun et al., 2014). These compounds have anti-inflammatory, antifungal, anti-yeast, and antibacterial activities (Arabski et al., 2012). Several researchers already found the potential of genus Entada as an antimicrobial agent. For example, Entada rheedii ethanol extract was reported to display moderate inhibitory against $S$. aureus and $C$. albicans (Ram et al., 2004). On the same species, the extract of methanol and fraction of Entada spiralis stem bark showed antifungal activity against $T$. mentagrophytes, $M$. gypeseum, T. mentagrophytes, $S$. aureus, and $S$. epidermis (Harun et al., 2014). Meanwhile, the chloroform extract of Entada spiralis leaves showed flavonoid, phenol (Mohammad, 2017). According to the previous result related to the potential agent of $E$. spiralis leaves as an antimicrobial agent, we aimed to enlarge the potential of the crude chloroform extract of $E$. spiralis leaves as food preservation against $S$. aureus, $E$. coli, and C. albicans.

\section{Methodology}

\section{Maceration}

E. spiralis leaves were obtained from Tasik Chini, Pahang, with voucher specimen no. KMS-5228. The 900 grams of dried leaves were later milled into a fine powder and macerated with $4 \mathrm{~L}$ of chloroform for $48 \mathrm{~h}$ Furthermore, the extracts were then filtered using a Whatman No. 1's filter paper. Chloroform was completely evaporated using a rotary evaporator at $40{ }^{\circ} \mathrm{C}$. Once thoroughly dried, the extract was placed in a $5 \mathrm{~L}$ Erlenmeyer and stored in a fridge at a temperature of $-4{ }^{\circ} \mathrm{C}$ before further analysis.

\section{Phytochemical Screening Test - Thin Layer Chromatography (TLC)}

TLC silica gel plate 60 F254 (Merck, Germany) was sized into $5 \times 3 \mathrm{~cm}$. The $5 \mu \mathrm{L}$ of the extract was spotted in the middle bottom of the TLC plate. The DCM/Hex (9/1) and $\mathrm{DCM} / \mathrm{MeOH}(9 / 1)$ solvent system solutions were used as mobile phases that were already tested from the preliminary research. The developing stage was conducted in a covered TLC developing chamber. The solvent was evaporated in a fume hood at $29^{\circ} \mathrm{C}$. Some colouring agents and wavelength, such as Vanillin, Dragendroff's, $\mathrm{FeCl} 3$, UV $365 \mathrm{~nm}$, UV $254 \mathrm{~nm}$, iodine pearl, and concentrated $\mathrm{H} 2 \mathrm{SO} 4$ was given onto the different developed plates to determine several bioactive compounds such as saponin, terpenoid, alkaloid, flavonoid, phenol, tannin, aromatic compound, and conjugated compound by $\mathrm{Rf}$ values calculations.

\section{Fractionation of Extract by Vacuum Liquid Chromatography (VLC)}

In the present study, a modified method from Mohammad (2017) was performed. It conducted a dilution of 10 grams of crude extract into $25 \mathrm{~mL}$ of chloroform solvent. The activated silica gel 60 PF254 (Merck, Germany) through a $24 \mathrm{~h}$ heating at $80^{\circ} \mathrm{C}$ was dipped into the extract solution. Sample and silica gel were kept agitated in a Hotplate Stirrer (Lab Tech, Korea) at $70{ }^{\circ} \mathrm{C}$ until was mixed gently. The silica gel was loaded into the VLC column until the solvent front reached $5 \mathrm{~cm}$ of the column height. Hexane was utilized to rinse the column by pressed the layer with Aspirator A-1000S (EYELA, Japan). The silica gel was stabilized by setting it down overnight in the VLC column. Ten (10) grams of the crude extract was submitted into VLC, eluted using a gradient system of DCM/Hex (9/1) and DCM/MeOH (9/1) as much as $1 \mathrm{~L}$ for each. The solvent system's use depended on the result of Rf value in preliminary research by using TLC. Furthermore, every $200 \mathrm{~mL}$ of the fraction, or based on the UV lamp band result, was separated respectively in Erlenmeyer flask. The fractions were tested with the TLC profile to identify the specific compounds. The extract for each solvent system was combined and evaporated in the rotary evaporator IKA HB10 Basic (Buchi, Switzerland) to dryness at $40{ }^{\circ} \mathrm{C}$.

\section{Disk Diffusion Agar, Kirby-Bauer Method}

The antimicrobial activity was conducted for crude $(\mathrm{CHCl} 3)$ and fractional (DCM/Hex (9/1), and $\mathrm{DCM} / \mathrm{MeOH}(9 / 1)$ ) extracts using a modified method from Harun et al. (2014) was performed in the present study. A $1600 \mathrm{mg} / \mathrm{mL}$ stock solution was formulated by dissolving $1.6 \mathrm{~g}$ of sample in $1 \mathrm{ml}$ of the specific solvent system depend on the polarity of the fractions. The serial two-fold dilution was done to make the several concentrations ranged from $12.5 \mathrm{mg} / \mathrm{mL}-1600 \mathrm{mg} / \mathrm{mL}$. The $20 \mathrm{ml} / \mu \mathrm{L}$ of 
each concentration was dipped onto paper discs (Whatman AA disc, $6 \mathrm{~mm}$, United States of America) by using a micro-pipette. The discs were evaporated at the laminar airflow cabinet (Erla CMP Series, Malaysia) until the solvent was evaporated completely. All discs were stored at $-5{ }^{\circ} \mathrm{C}$ in Chiller LC-213LD (Law Chain, Taiwan) for further analysis.

The positive control of antifungal, gram-negative bacteria and gram-positive respectively employed $100 \mu \mathrm{L}$ Nystatin (Oxoid, United Kingdom), $10 \mu \mathrm{L}$ ampicillin (Oxoid, United Kingdom), and $10 \mu \mathrm{L}$ Gentamicin (Oxoid, United Kingdom). The Chloroform, DCM/Hex (9/1), and $\mathrm{DCM} / \mathrm{MeOH}(9 / 1)$ (Merck, Germany) was used as a negative control. The pure culture of E. coli, S. aureus, and the fungal strain C. albicans were collected from the Basic Medicine Science of International Islamic University of Malaysia. Bacterial and fungi were incubated in $24 \mathrm{~h}$ at 37 ${ }^{\circ} \mathrm{C}$ in Mueller Hilton-Agar (Oxoid, United Kingdom) and Saboraud Dextrose Agar (Becton, United States of America). The OD of bacteria was 0.1 at $600 \mathrm{~nm}$ UV-Vis spectrophotometer (Secomam, United States of America). Thus, the standard inoculation of bacteria was standardized at $1.5 \times 106 \mathrm{cel} / \mathrm{mL}$ and was swabbed on an agar plate using a sterile cotton bud. The sterile paper discs were aseptically transferred onto the inoculated agar plates' surfaces and were submitted to $24 \mathrm{~h}$ of incubation at $37{ }^{\circ} \mathrm{C}$. The effect of the antimicrobial agent was indicated through a clear zone. The determination of this assay was conducted in triplicate.

\section{Minimum Inhibitory Concentration (MIC), by Broth Microdilution Assay}

The present study modified a method by Harun et al. (2014) and Mohamad (2012) by diluting the microbial stock into the Mueller Hilton-Broth (Oxoid, United Kingdom) to an absorbance of 0.11 at $600 \mathrm{~nm}$ for bacteria and Saboraud Dextrose Broth (Becton, United States of America) to the absorbance of 0.6 at $450 \mathrm{~nm}$ for fungi. The $1 \mathrm{~mL}$ inoculum was added to $100 \mathrm{~mL}$ of sterile broth and diluted until a reached number of OD 105 cells $/ \mathrm{mL}$ for fungi and $1.5 \times 1064$ cells $/ \mathrm{mL}$ for bacteria. The first row of the 96 well microtiter plate (Trueline, United States of America) was filled with $180 \mu \mathrm{L}$ of $1 / 100$ diluted microbial solution and $100 \mu \mathrm{L}$ for the rest. Therefore, the $20 \mu \mathrm{L}$ of two-fold serial dilution $50 \mathrm{mg} / \mathrm{mL} \quad-0.39 \mathrm{mg} / \mathrm{mL}$ concentration extract was diluted with DMSO. The microplates were incubated at $37^{\circ} \mathrm{C}$ for $24 \mathrm{~h}$. The $20 \mathrm{uL} 0.5 \%$ (w/v) of MTT (3-(4,5-dimethylthiazol-2-yl) - 2,5 diphenyl tetrazolium bromide (Life Technologies, United States of America) and Phosphate Buffered Saline solution (Base, Singapore) was put to each well and re-incubation for $2 \mathrm{~h}$ for fungi and bacteria. The yellow color indicated the inhibition of microbial growth; meanwhile, the dark blue indicates microorganisms' presence.

\section{Minimum Bactericidal Concentrations (MBC) and Fungicidal Concentrations (MFC)}

The MBC and MFC were used for each concentration on the solvent system of all microorganisms tested. The $\mathrm{MBC}$ and MFC pursued the lowest concentration by calculating fewer than three colonies to achieve approximately $99 \%$ inhibition growth. $100 \mu \mathrm{L}$ of the mixture from MIC that showed the positive result was incubated on SDA (for fungi) and MHA (for bacteria) at $37^{\circ} \mathrm{C}$ for $24 \mathrm{~h}$.

\section{Total Phenolic Content (TPC)}

The Folin-Ciocalteu assay was performed to identify the amount of TPC in E. spiralis leaves based on Mohamad's method (2012). $50 \mu \mathrm{L}$ of the extract was formulated from $2 \mathrm{mg} / \mathrm{mL}$ with the original solvent. The standard of gallic acid solution $(7.8-1000 \mu \mathrm{L} / \mathrm{mL})$ was diluted into $100 \mu \mathrm{L}$ of methanol, where the blank was using methanol. The sample was diluted with a ratio of $4: 1$ (water: Folin- Ciocalteu phenol reagent) and $50 \mu \mathrm{L}$ of $1 \mathrm{M}$ Sodium carbonate $\left(\mathrm{Na}_{2} \mathrm{CO}_{3}\right)$ solution in water. $25 \mu \mathrm{L}$ sample or standard combined with $100 \mu \mathrm{L}$ Folin Ciocalteu phenol reagent were filled into a 96 -well plate and incubate for $5 \mathrm{~min}$ at $37^{\circ} \mathrm{C} .75 \mu \mathrm{L} \mathrm{Na}_{2} \mathrm{CO}_{3}$ was added and was kept from light for $1 \mathrm{~h}$. The result's absorbance was analyzed at $765 \mathrm{~nm}$ against blank by a multi-detection microplate reader (Infinite M200 Nanoquant, Switzerland).

\section{Results}

\section{Phytochemical Screening of Crude Extract}

The phytochemical screening results of E. spiralis crude extract by TLC can be seen in Table 1. Crude extract showed several bioactive compounds such as; terpene, steroid, terpenoid, phenol, tannin, saponin, flavonoid, and aromatic compound, as shown in Figure 1.

\section{Antimicrobial Activity Assay by Kirby-Bauer Test}

The chloroform crude extract strongly inhibited the E. coli with an inhibition zone of $10.67 \mathrm{~mm}$ in Table 2, followed by C. albican and S. aureus with an inhibition zone of 10.33 and $9.67 \mathrm{~mm}$, respectively. Moreover, the fraction $\mathrm{DCM} / \mathrm{MeOH}(9 / 1)$ extract was strongly inhibited the E. coli with a $12.00 \mathrm{~mm}$ inhibition zone in Table 3, followed by $C$. albicans and $S$. aureus with an inhibition zone of 9.00 and $11.67 \mathrm{~mm}$, respectively. Among all microorganisms that were used, E coli was found to be the most susceptible, whereas $S$. aureus and C. albicans were less susceptible to all extracts. 
Table 1: TLC Analysis of Entada spiralis Crude Extract

\begin{tabular}{|c|c|c|c|c|}
\hline \multirow{2}{*}{$\begin{array}{l}\text { Reagent } \\
\text { Sprayer }\end{array}$} & \multicolumn{4}{|c|}{ Spot on TLC plate } \\
\hline & Total spot & Color & $\mathbf{R f}$ & Compound \\
\hline Nature & 7 & $\begin{array}{c}\text { Yellow } \\
\text { Yellow } \\
\text { Dark Yellow } \\
\text { Blue Green } \\
\text { Grey } \\
\text { Dark Green } \\
\text { Yellow }\end{array}$ & $\begin{array}{c}0.1125 \\
0.1625 \\
0.2 \\
0.275 \\
0.6875 \\
0.75 \\
0.9375\end{array}$ & $\begin{array}{l}\text { Neoxanthin } \\
\text { Violaxanthin } \\
\text { Lutein } \\
\text { Chlorophyll b } \\
\text { Anthocyanin } \\
\text { Pheophytin a } \\
\text { Carotene }\end{array}$ \\
\hline UV254 Light & 7 & $\begin{array}{c}\text { Grey } \\
\text { Grey } \\
\text { Dark Grey } \\
\text { Dark Grey } \\
\text { Dark Grey } \\
\text { Dark Grey } \\
\text { Dark Grey }\end{array}$ & $\begin{array}{c}0.1125 \\
0.1625 \\
0.2 \\
0.275 \\
0.6875 \\
0.75 \\
0.9375\end{array}$ & $\begin{array}{l}\text { Aromatic } \\
\text { compound }\end{array}$ \\
\hline Sulphuric Acid & 3 & $\begin{array}{l}\text { Green } \\
\text { Yellow } \\
\text { Pink }\end{array}$ & $\begin{array}{c}0.25 \\
0.5 \\
0.6875\end{array}$ & $\begin{array}{l}\text { Tertepenes } \\
\text { Steroid } \\
\text { Steroid }\end{array}$ \\
\hline Iodine & 3 & $\begin{array}{c}\text { Brown } \\
\text { Brown } \\
\text { Dark Brown }\end{array}$ & $\begin{array}{c}0.25 \\
0.5 \\
0.6875\end{array}$ & $\begin{array}{c}\text { Aromatic and } \\
\text { organic } \\
\text { compound }\end{array}$ \\
\hline UV365 Light & 1 & Fluoresence & 0.6875 & Terpenoid \\
\hline $\mathrm{FeCl}_{3}$ & 2 & $\begin{array}{l}\text { Green } \\
\text { Green }\end{array}$ & $\begin{array}{c}0.1125 \\
0.357\end{array}$ & $\begin{array}{l}\text { Phenol } \\
\text { Tannin }\end{array}$ \\
\hline Vanillin & 3 & $\begin{array}{c}\text { Dark Purple } \\
\text { Green } \\
\text { Violet }\end{array}$ & $\begin{array}{c}0.175 \\
0.2625 \\
0.5375\end{array}$ & $\begin{array}{c}\text { Saponin } \\
\text { Furastanol } \\
\text { Spirostanol }\end{array}$ \\
\hline $\mathrm{AlCl}_{3}$ & 1 & Orange & 0.6155 & Flavonoid \\
\hline
\end{tabular}




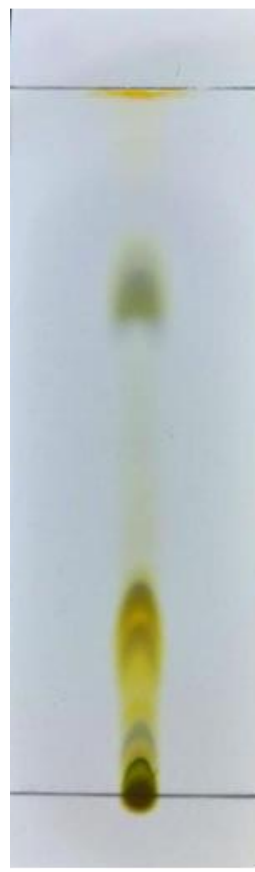

(a)

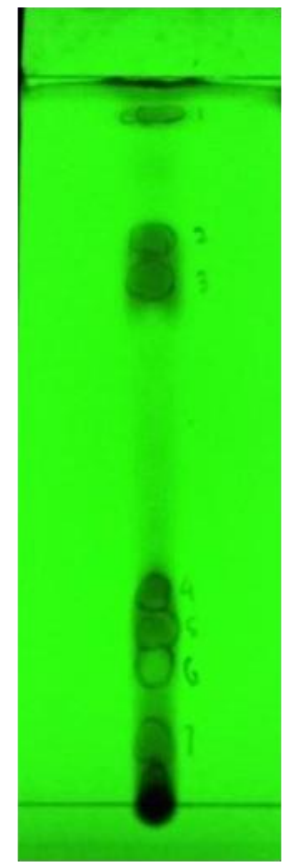

(b)

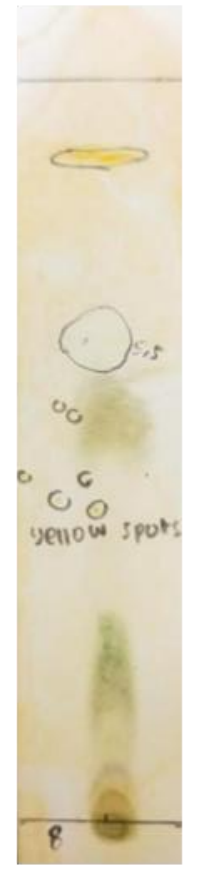

(c)

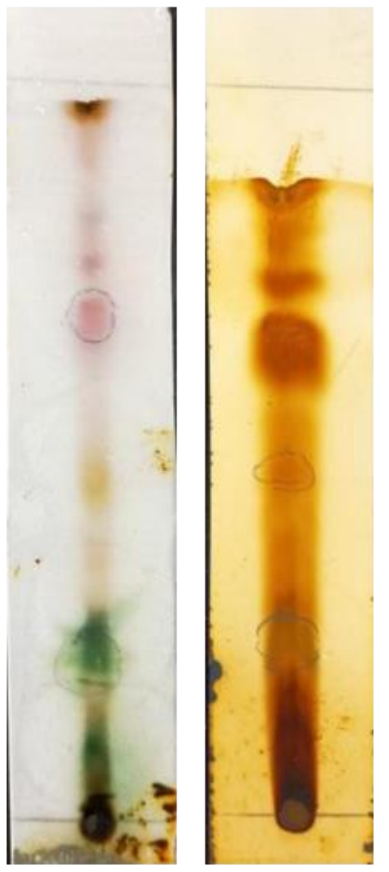

(d)

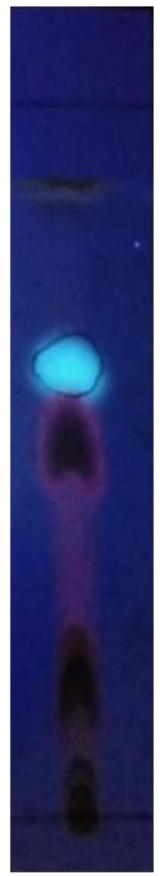

(f)

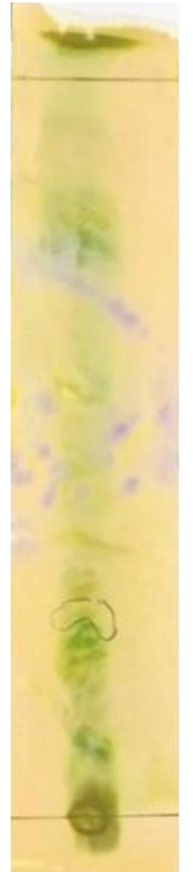

(g)

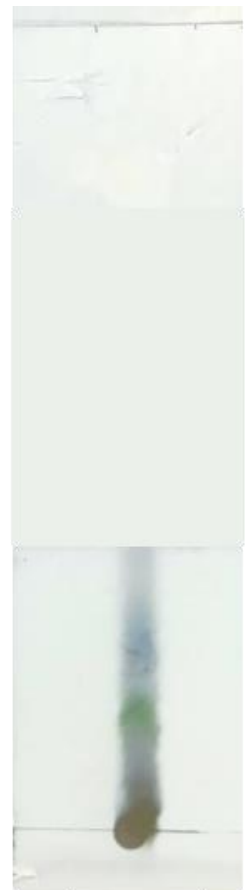

(h)

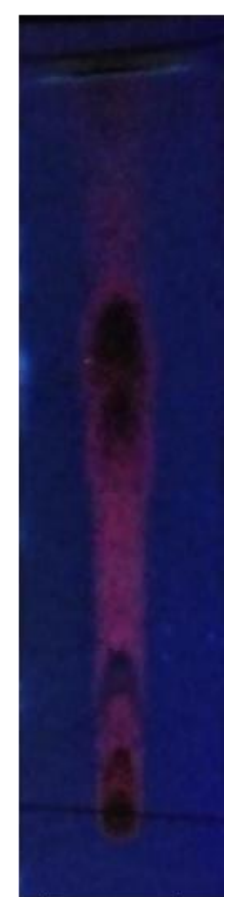

(i)

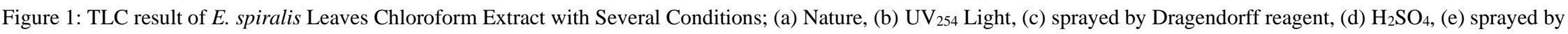
Iodine, (F) $\mathrm{UV}_{365}$ Light, (g) sprayed by $\mathrm{FeCl}_{3}$, (h) sprayed by vanillin reagent, (I) sprayed by $\mathrm{AlCl}_{3}$ 
Table 2: In vitro Antifungal and Antimicrobial Activity of Fraction and Crude Extract of E. spiralis Leaves

\begin{tabular}{|c|c|c|c|c|}
\hline \multirow[t]{2}{*}{ Extract } & \multirow[t]{2}{*}{ Concentration (mg/mL) } & \multicolumn{3}{|c|}{ Inhibition zone $(\mathrm{mm})^{\mathrm{a}}$} \\
\hline & & $\mathrm{EC}$ & SA & CA \\
\hline \multirow{5}{*}{ DCM/Hex } & 12.5 & - & - & - \\
\hline & 25 & - & - & - \\
\hline & 50 & - & - & - \\
\hline & 100 & - & - & - \\
\hline & 200 & $6.67 \pm 0.577^{\mathrm{c}}$ & - & - \\
\hline \multicolumn{2}{|c|}{ Negative control DCM/Hex } & - & - & - \\
\hline \multirow{5}{*}{ Chloroform } & 12.5 & $7.33 \pm 1.155^{\mathrm{bc}}$ & $7.17 \pm 0.288^{b}$ & \\
\hline & 25 & $7.67 \pm 0.577^{\mathrm{bc}}$ & $7.33 \pm 0.577^{b}$ & \\
\hline & 50 & $7.67 \pm 0.577^{\mathrm{bc}}$ & $7.67 \pm 1,443^{\mathrm{ab}}$ & \\
\hline & 100 & $8.33 \pm 0.577^{\mathrm{abc}}$ & $7.77 \pm 1,328^{\mathrm{ab}}$ & \\
\hline & 200 & $9.00 \pm 1^{\mathrm{ab}}$ & $7.67 \pm 0.577^{\mathrm{ab}}$ & \\
\hline \multicolumn{2}{|c|}{ Negative control Chloroform } & - & - & - \\
\hline \multirow{5}{*}{ DCM/МеОН } & 12.5 & $8.33 \pm 0.577^{\mathrm{abc}}$ & $7.33 \pm 1,527^{\mathrm{b}}$ & $6.33 \pm 0.577^{b c}$ \\
\hline & 25 & $8.67 \pm 0.577^{\mathrm{ab}}$ & $7.67 \pm 0,527^{\mathrm{ab}}$ & $6.67 \pm 0.577^{\mathrm{bc}}$ \\
\hline & 50 & $9.00 \pm 1^{\mathrm{ab}}$ & $8.33 \pm 0,577^{\mathrm{ab}}$ & $7.0 \pm 0^{\mathrm{b}}$ \\
\hline & 100 & $9.00 \pm 0^{\mathrm{ab}}$ & $9.167 \pm 0,763^{\mathrm{a}}$ & $7.0 \pm 0^{\mathrm{b}}$ \\
\hline & 200 & $9.67 \pm 0.577^{\mathrm{a}}$ & $9.00 \pm 1^{\mathrm{a}}$ & $7.0 \pm 0^{\mathrm{b}}$ \\
\hline \multicolumn{2}{|c|}{ Negative control DCM/MeOH } & - & - & - \\
\hline Nystatin & 100 & & & $24.0 \pm 1$ \\
\hline Ampicillin & 10 & & $24.33 \pm 1.527$ & \\
\hline Gentamicin & 10 & $32.67 \pm 0.577$ & & \\
\hline
\end{tabular}

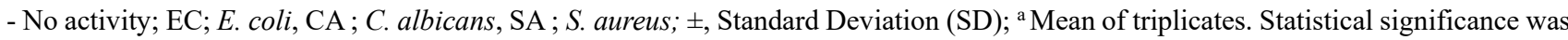
determined using ANOVA. Differences were analyzed significant $(\mathrm{P}<0.05)$ on the same microbes. The different notation means significantly different values.

Table 3: In vitro Antimicrobial and Antifungal Activity of DCM:MeOH Fraction and Crude Extract of E. spiralis Leaves

\begin{tabular}{|c|c|c|c|c|}
\hline \multirow[t]{2}{*}{ Extract } & \multirow[t]{2}{*}{ Concentration (mg/mL) } & \multicolumn{3}{|c|}{ Inhibition zone $(\mathrm{mm})^{\mathrm{a}}$} \\
\hline & & $\mathrm{EC}$ & SA & CA \\
\hline \multirow{3}{*}{ Chloroform } & 400 & $9.33 \pm 0.577^{b}$ & $7.67 \pm 0.577^{\mathrm{b}}$ & $8.67 \pm 0,577^{\mathrm{ab}}$ \\
\hline & 800 & $10.33 \pm 1.154^{\mathrm{ab}}$ & $8.833 \pm 1,607^{\mathrm{ab}}$ & $8.67 \pm 1,155^{\mathrm{ab}}$ \\
\hline & 1600 & $10.67 \pm 1.154^{\mathrm{ab}}$ & $9.667 \pm 2,081^{\mathrm{ab}}$ & $10.33 \pm 2,309^{a}$ \\
\hline \multicolumn{2}{|c|}{ Negative control Chloroform } & - & - & - \\
\hline \multirow{3}{*}{ DCM / МeOH } & 400 & $9.00 \pm 1^{b}$ & $8.00 \pm 0^{\mathrm{b}}$ & $7.33 \pm 0,577^{b}$ \\
\hline & 800 & $11.33 \pm 0.577^{\mathrm{a}}$ & $9.67 \pm 0,577^{\mathrm{ab}}$ & $8.33 \pm 1,155^{\mathrm{ab}}$ \\
\hline & 1600 & $12.00 \pm 1^{\mathrm{a}}$ & $11.67 \pm 2,887^{\mathrm{a}}$ & $9.00 \pm 0^{\mathrm{ab}}$ \\
\hline \multicolumn{2}{|c|}{ Negative control DCM/MeOH } & - & - & - \\
\hline Nystatin & 100 & & & $24.0 \pm 1$ \\
\hline Ampicillin & 10 & & $24.33 \pm 1.527$ & \\
\hline Gentamicin & 10 & $32.67 \pm 0.577$ & & \\
\hline
\end{tabular}

- No activity; EC; E. coli, CA; C. albicans, SA; S. aureus; \pm , Standard Deviation (SD); ${ }^{a}$ Mean of three replicates Statistical significance was determined using ANNOVA. Differences were analyzed significant $(\mathrm{P}<0.05)$ on the same microbes. The different notation means significantly different values. 


\section{Determination of MIC, MFC and MBC}

The MIC results of the positive result fractions against bacteria and fungi are presented in Table 4. The Chloroform crude extract showed the MIC value of 1.563 $\mathrm{mg} / \mathrm{mL}$ against both $E$. coli and $S$. aureus, and 0.781 $\mathrm{mg} / \mathrm{mL}$ against $C$. albicans. Meanwhile, fraction $\mathrm{DCM} / \mathrm{MeOH}(9 / 1)$ extract showed the MIC value of 1.563 $\mathrm{mg} / \mathrm{mL}$ against $E$. coli and $3.125 \mathrm{mg} / \mathrm{mL}$ against both $S$. aureus and C. albicans.

According to the result of Minimum Bactericidal Concentration (MBC), the chloroform extract had the lowest $\mathrm{MBC}$ result against $E$. coli, $S$. aureus, with 0.39 and $0.781 \mathrm{mg} / \mathrm{mL}$ compared to fraction $\mathrm{DCM} / \mathrm{MeOH}(9 / 1)$ with $\mathrm{MBC}$ results of 0.781 and $1.563 \mathrm{mg} / \mathrm{mL}$ and positive control $0.39 \mathrm{mg} / \mathrm{mL}$ for Gentamicin $(\mu \mathrm{g} / \mathrm{mL})$ and 0.39 $\mathrm{mg} / \mathrm{mL}$ for Ampicillin $(\mu \mathrm{g} / \mathrm{mL})$. On the other hand, chloroform extract also gave lower MFC result $(0.781$ $\mathrm{mg} / \mathrm{mL}$ ) compared to $\mathrm{DCM} / \mathrm{MeOH}(9 / 1)$ with an MFC result of $1.563 \mathrm{mg} / \mathrm{mL}$, but still fell behind the positive control Nystatin $(\mu \mathrm{g} / \mathrm{mL})$ with an MFC result of 0.39 $\mathrm{mg} / \mathrm{mL}$. In conclusion, the chloroform extract has a promising role as an antimicrobial agent against significant microorganisms, especially bacteria.

Table 4: Minimum Inhibitory Concentration, Minimum Fungicidal (MFC) and Bactericidal Concentration $(\mathrm{mg} / \mathrm{mL})$ of E. spiralis Crude Extract

\begin{tabular}{lccccccc}
\hline \multirow{2}{*}{ Extract } & \multicolumn{2}{c}{ MBC } & MFC & \multicolumn{3}{c}{ MIC } \\
\cline { 2 - 7 } & EC & SA & CA & EC & SA & CA \\
\hline $\begin{array}{l}\text { Chloroform } \\
\text { crude } \\
\text { extract }\end{array}$ & 0.390 & 0.781 & 0.781 & 1.563 & 1.563 & 0.781 \\
$\begin{array}{l}\text { Fraction } \\
\text { (DCM }\end{array}$ & 0.781 & 1.563 & 1.563 & 0.781 & 3.125 & 3.125 \\
/MeOH) & & & & & & \\
$\begin{array}{l}\text { Gentamicin } \\
(\mu \mathrm{g} / \mathrm{mL})\end{array}$ & 0.390 & - & - & 0.390 & - & - \\
$\begin{array}{l}\text { Nystatin } \\
(\mu \mathrm{g} / \mathrm{mL})\end{array}$ & - & - & 0.390 & - & - & 0.390 \\
$\begin{array}{l}\text { Ampicillin } \\
(\mu \mathrm{g} / \mathrm{mL})\end{array}$ & & 0.390 & - & - & 0.390 & - \\
\hline
\end{tabular}

\section{Total Phenolic Content}

Total phenolic content of $E$. spiralis leaves extracted by chloroform, fraction $\mathrm{DCM} / \mathrm{MeOH}(9 / 1)$, and fraction $\mathrm{DCM} / \mathrm{Hex}(1 / 9)$ were $50.56 \pm 0.089,51.913 \pm 0.188,24.16$ \pm 0.175 the concentration of phenolic was in terms of equivalent (mg GAE/g of the dry weight of extract), separately.

\section{Discussion}

In the Kirby-Bauer method, the restraint zone's size expressed the compound's competences wherein the highest the zone, the more powerful the compound. Higher active compounds from the extracts could cause the higher inhibition zones recognized at $\mathrm{s}$ higher concentration of all extracts. Fractionation in several plant extracts brought about improved movement, yet others brought about the loss of the action. For instance, in an extract of fraction DCM/Hex (1/9), the inhibition was only detected at a concentration of $200 \mathrm{mg} / \mathrm{mL}$ against E. coli with zone inhibition of 7. Since the $\mathrm{CHCl} 3(100 \%)$ and $\mathrm{DCM} / \mathrm{MeOH}$ (9/1) extract showed promising anti-dermatophytes and antibacterial activity, thus it was chosen to undergo fractionation and was further assayed to investigate the effectiveness of the fractions, except DCM/Hex (1/9). The greatest inhibition zone against $\mathrm{C}$. albicans was obtained from fraction Chloroform $(\mathrm{CHCl} 3)$ extract with an inhibition zone of $10.33 \mathrm{~mm}$. DCM/MeOH (9/1) effectively killed S. aureus and $E$. coli with an inhibition zone of 11.67 and $12 \mathrm{~mm}$, respectively. Those results were determined by the polarity of the solvent's polarity that may be affected by the bioactive compound after the fractionation process and the chemical nature of its bioactive constituents.

The antifungal and antibacterial potency of several plants was related to secondary metabolites established in some fractionations of the unrefined concentrate, permits the appropriation of bio-active compounds into solvents as per their polarity. The current investigation's perception showed that the antifungal and antibacterial activity of the fraction $\mathrm{DCM} / \mathrm{MeOH}(9 / 1)$ and $\mathrm{CHCl}_{3}(100 \%)$ extract of E.spiralis leaves maybe showed that the active compound was either modestly nonpolar or polar. This may fill into the natural dissolvable that can be utilized in removing dynamic elements of E.spiralis leaves. The phytochemical compound can be isolated. For example, the related movement against contagious and antibacterial action may be associated with the nearness of phytochemicals, such as alkaloid, flavonoid, saponin, sterol, and tannins in the individual portion that previously controlled by TLC profile in past study.

The inhibitions were supported by microdilution assay in which the chloroform crude extract gave the highest MIC value of $1.563 \mathrm{mg} / \mathrm{mL}$ against E. coli, $1.563 \mathrm{mg} / \mathrm{mL}$ against S. aureus, $0.781 \mathrm{mg} / \mathrm{mL}$ against C. albicans. As mentioned before, the polarity of the fraction will affect the compound that, in turn, will affect the efficiency of antimicrobial activity. For an extract of fraction, DCM/Hex (1/9) has nonpolar properties. The nonpolar solution contains only a few bioactive compounds such as; flavonoid, sterol, phenol, alkaloid (Widyawati, 2014), terpenoid (Liu et al., 2011), and diterpenoid (Hidayat, 2014) that dissolved by hexane solvent. Meanwhile, in 
semipolar - polar extract of fraction DCM/MeOH $(9 / 1)$ has more bioactive compounds such as sterol, phenol, flavonoid, and alkaloid (Widyawati, 2014). In Semipolar polar extract of $\mathrm{DCM} / \mathrm{MeOH}(9 / 1)$ may also have polar properties such as alkaloid, phenolic, saponin, carotenoid, tannin, amino acid, and glycoside (Elfirta, 2018).

Terpenoids, tannins, phenolics, and flavonoids are secondary metabolites compounds that naturally exist in several types of plants. The secondary metabolites realized with pharmacological significance are commonly known as bioactive compounds (Swabha, 2018). These bioactive compounds will increase lymphocyte activity, such as macrophage cells, especially compounds such as phenolics and its derivatives. Phenolics play several important functions in plants as an immunomodulator and antioxidant. They give opposition against microbes and predators, other than that phenolics protect cellular membranes and tissues from lipid peroxidation, and fix DNA by electron transfer responses (Shankar et al., 2007).

Flavonoids, particularly catechins, have been known for their antimicrobial activity in Gram-positive and Gramnegative microorganisms (Tsuchiya 2015). Catechins will have collaborate with the cell layer of microbes by authoritative to the lipid bilayer and by inactivating or hindering the union of intracellular and extracellular compounds (Reygaert, 2014). Tannins also fill as guards against microorganisms. Their antimicrobial activity method might be identified with their capacity to idle microbial adhesin, cell envelope transport protein, catalyst several enzymes, that properly known as astringency (Bobbarala, 2012). They are fit for restricting metal particles related to the development of microscopic organisms. In this manner, by consolidating with $\mathrm{Ca} 2+$ particles engaged with Gram-negative bacteria's structure, dense tannins influence the bacterial wall cell, disrupting the retention of minor components fundamental for bacterial development (Joseph, 2016).

\section{Conclusion}

The $\mathrm{CHCl} 3(100 \%)$ extract of E. spiralis uncovered several bioactive compounds such as tannins, saponin, glycosides, phenol, flavonoid, triterpenoid, and aromatic compound through Thin Layer Chromatography (TLC). The highest zone inhibition zone for E. coli was obtained from $\mathrm{DCM} / \mathrm{MeOH}(9 / 1)$ extract with a diameter of 12.00 $\pm 1 \mathrm{~mm}$. The highest inhibition zone for $\mathrm{S}$. aureus was obtained from DCM/MeOH (9/1) extract with a diameter of $11.67 \pm 2.887 \mathrm{~mm}$. The greatest inhibition zone for C. albicans was obtained from $\mathrm{CHCl} 3(100 \%)$ extract with a diameter of $10.33 \pm 2.309 \mathrm{~mm}$. The inhibitions were supported by microdilution assay in which the chloroform crude extract gave the highest MIC value of $1.563 \mathrm{mg} / \mathrm{mL}$ against E. coli, $1.563 \mathrm{mg} / \mathrm{mL}$ against $\mathrm{S}$. aureus, 0.781 $\mathrm{mg} / \mathrm{mL}$ against $\mathrm{C}$. albicans. This study suggests that the leaf extract of Entada spiralis has great potential to become a natural preservative for foods, replacing chemical preservatives. A future study is needed to distinguish the isolated specific bioactive compounds that can be done by utilizing an LC-MS or GC-MS examination.

\section{Acknowledgements}

The authors would like to express gratitude to The Ministry of Science and Technology for SF grant no:0050055 for the financial support, Kulliyyah of Pharmacy, International Islamic University Malaysia (IIUM), Kuantan, Pahang, Malaysia, Pn. Norhayati Abdullah. Tasik Cini, Pahang for the supplier of Entada spiralis Ridl leaves, and Faculty of Agricultural Technology, University of Brawijaya, Indonesia for organizing the research join the program.

\section{Conflict of Interest}

Authors have no conflicts of interest with this publication.

\section{References}

Arabski, M. Aneta, W.C., Czerwonka, G., Anna, L., \& Kaca, W. (2012). Effects of Saponins Against Clinical E. coli Strains and Eukaryotic Cell Line. Journal of Biomedicine and Biotechnology, 2012(286216), 1-6. doi:10.1155/2012/286216

Bobbarala, V. (2012). Antimicrobial Agents. Croatia. In Tech Published.

Chaffin, W. L. (2008). Candida albicans Cell Wall Protein. Microbiology and Molecular Biology, 72(3), 495-544. doi: 10.1128/MMBR.00032-07

Elfirta, R.R., Syamsul, F., Dimas, A., \& Tien, L. (2018). Identification of Active Compounds and Antifungal Activity of Toona sinensis Leaves Fractions Against Wood Rot Fungi. Journal of Biological Diversity, 19(4), 1313-1318. doi: 10.13057/biodiv/d190418

Harun, Aiza, Siti, Zaiton M.S., Norazian, M.H., \& Neni K. C. M. R. (2014). Bioactive Terpenoid from The Stem Bark of Entada spiralis Ridl. (Sintok). Proceedings of the International Conference on Science, Technology and Social Sciences (ICSTSS) 2012, 605 - 615.

Hidayat, J., Ay, L., Margaret, Hanna, Y., \& Lies, K. W. (2014). Hexane Neem Leaf Extract More Potent than Ethanol Extract Against Aspergillus flavus. Universa Medicina, 33(3), 172-178. doi:10.18051/UnivMed.2014.v33.171-178

Joseph, N., Mirelle, A. F. R., Matchawe, C., Patrice, D. N., \& Josaphat, N. (2016). Evaluation of The Antimicrobial Activity of Tannin Extracted from The Barks of Erythrophleum guineensis (Caesalpiniaceae). Journal of Pharmacognosy and Phytochemistry, 5(4), 287-291. 
Liu, J., Wang, C., Wang, Z., Zhang, C., Lu, S., \& Liu, J. (2011). The Antioxidant and Free-radical Scavenging Activities of Extract and Fractions from Corn Silk (Zea mays L.) and Related Flavone Glycosides. Food Chemistry, 126(1), 261-269. doi: 10.1016/j.foodchem.2010.11.014

Mohamad, Sharifah Nurul. (2017). Bioassay Guide Isolation and Characterization of Compounds with Antioxidant Activities from The Leaves of Entada spiralis Ridl. (Sintok). Malaysia: International Islamic University Malaysia.

National Park. (2019). National Parks. Retrieved from https://www.nparks.gov.sg/

Ram, A. J., Bhakshu, L. Md., \& Venkata Raju, R.R. (2004). In Vitro Antimicrobial Activity of Certain Plants from Eastern Ghats, India, Used for Skin Diseases. Journal of Ethonopharmacology, 90(2), 353-357. doi:10.1016/j.jep.2003.10.013

Reygaert, Wanda. (2017). Antimicrobial Mechanisms of Escherichia coli. Escherichia coli - Recent Advances on Physiology, Pathogenesis and Biotechnological Applications. London: Intech Open.
Shankar, S., Singh, G., \& Srivastava R. K., (2007). Chemoprevention by Resveratrol: Molecular Mechanisms and Therapeutic Potential. Frontiers in bioscience: a journal and virtual library, 12, 48394854. doi: $10.2741 / 2432$

Swabha, T., (2018). Bioactive Compounds in Medicinal Plants: A Condensed Review. SEJ Pharmacognosy and Natural Medicine, 1(1), 1-35.

Tsuchiya, H. (2015). Membrane Interactions of Phytochemicals as Their Molecular Mechanism Applicable to The Discovery of Drug Leads from Plants. Molecules, 20, 18923-18966. doi: 10.3390/molecules201018923

Widyawati, P.S., Wijaya, C.H., Harjosworo, P.S., \& Sajuthi, D. (2011). Evaluation of Antioxidant Activity of Beluntas (Pluchea indica Less) leaf Extract Based on Differences in Leaf Segments. Recapitulation Journal of Food Technology, 5(1), 1-14.

Zhang, Ping, Fei, W., Jianying, H. \& Robert, S. (2013). Exploring the Relationship Between Drug SideEffects and Therapeutic Indications. AMIA Annual Symposium Proceeding Archive, 2013, 1568-1577. 